\title{
Acute and chronic bovine pulmonary edema and emphysema in Uruguay ${ }^{1}$
}

\author{
Ricardo A. Costa ${ }^{2}$, Carlos Schild ${ }^{2}$, Caroline S. Silveira², Melissa Macías-Rioseco², \\ Santiago Mirazo $^{3}$, Leticia Maya ${ }^{4}$, Juan Clariget $^{2}$ and Franklin Riet-Correa ${ }^{2 *}$
}

\begin{abstract}
Costa R.A., Schild C., Silveira C.S., Macías-Rioseco M., Mirazo S., Maya L., Clariget J. \& Riet-Correa F. 2018. Acute and chronic bovine pulmonary edema and emphysema in Uruguay. Pesquisa Veterinária Brasileira 38(10):1929-1934. Instituto Nacional de Investigación Agropecuaria, Estación Experimental INIA La Estanzuela, Ruta 50 Km 11, Colonia del Sacramento, Colonia, Uruguay. E-mail: frcorrea@inia.org.uy

An outbreak of pulmonary edema and emphysema with acute and chronic cases is reported in a farm in Uruguay. In a herd of 40 Hereford steers, 20 died. The deaths began four days after a change of paddock, from an old pasture of Avena sativa to a lush growing pasture of the same grass. Acutely affected animals showed severe dyspnea, sialorrhea, cough, and subcutaneous edema, and died within 72 hours. Chronically affected steers showed dyspnea, respiratory noises, weight loss, and intolerance to exercise. The deaths began four days after the change of paddock. Ten days after the first death, the steers were withdrawn from the pasture, but continued dying throughout the following 40 days. Twenty animals died and six were necropsied. Grossly, the lungs were diffusely armed and glistening, with reddish and crepitant cut surface, and presented alveolar septae sharply distended by edema and emphysema. There was subpleural emphysema with air blebs distributed across the pleural surface. Presence of Dictyocaulus viviparus was observed in three steers. In some animals, the trachea was diffusely reddish with presence of pink foam; in some others, there was bloody liquid in the tracheal lumen. Histologic examination showed severe diffuse alveolar and interstitial emphysema, hyaline membranes adhered to the alveolar wall, thickening of the interlobular septae with proliferation of type II pneumocytes, and moderate-to-severe multifocal histiocytic, neutrophilic and eosinophilic infiltrate. In the trachea, there was submucosal hemorrhage and moderate multifocal eosinophilic and lymphocytic infiltrate. The steers with chronic signs presented similar lung lesions, but multifocal pulmonary fibrosis and cardiac dilatation were also observed. The diagnosis of acute bovine pulmonary emphysema and edema (ABPE) was based on the occurrence of the disease after introduction of the herd in a lush green pasture, on the characteristic gross and histologic lesions, and on the absence of other toxic or infectious agents causing similar lesions. Cattle raisers should be alert to the risks of occurrence of this disease after the introduction of the herds into paddocks with green and lush pastures.
\end{abstract}

INDEX TERMS: Pulmonary edema, pulmonary emphysema, cattle, Uruguay, L-tryptophan, 3-methylindole, fog fever, atypical interstitial pneumonia, bovine, pathology.

\footnotetext{
${ }^{1}$ Received on March 31, 2018.

Accepted for publication on April 3, 2018.

${ }^{2}$ Instituto Nacional de Investigación Agropecuaria (INIA), Estación Experimental INIA La Estanzuela, Ruta $50 \mathrm{Km}$ 11, Colonia del Sacramento, Colonia, Uruguay. *Corresponding author: frcorrea@inia.org.uy

${ }^{3}$ Faculdade de Ciências, Universidade de La Republica (Udelar), Montevideo, Uruguay.

${ }^{4}$ Laboratório de Virologia Molecular, Universidade de La Republica (Udelar), Centro Universitario Region Litoral Norte Sede Salto (CENUR), Uruguay.
}

RESUMO.- [Edema e enfisema pulmonar agudo e crônico em bovinos do Uruguai.] Descreve-se um surto de edema e enfisema pulmonar com casos agudos e crônicos em bovinos em uma criação semi-intensiva no Uruguai. De um lote de 40 novilhos da raça Hereford morreram 20. As mortes começaram quatro dias após uma mudança de alimentação, de uma pastagem mais velha de Avena sativa, para uma pastagem recentemente plantada de aveia que estava em brotação. Os animais afetados 
apresentaram sinais clínicos agudos de dispneia, sialorreia, tosse e alguns desenvolveram edema subcutâneo, morrendo em até 72 horas. Outros novilhos mais cronicamente afetados apresentaram dispneia, ruídos respiratórios, perda de peso e intolerância ao exercício. As mortes começaram quatro dias após a mudança de pastagens. Dez dias após a primeira morte, os novilhos foram retirados do pasto, mas morreram ainda durante 40 dias mais. Ao total, morreram vinte animais e seis foram necropsiados. Nas necropsias dos animais mortos na fase aguda os pulmões estavam difusamente armados e brilhosos e ao corte de coloração avermelhada e crepitante, com os septos alveolares acentuadamente distendidos por edema e enfisema. Havia enfisema subpleural caracterizado por bolhas de ar distribuídas pela superfície pleural. Em três bovinos havia ainda presença de Dictyocaulus viviparus. Alguns animais apresentaram a traqueia difusamente avermelhada com espuma de coloração rósea ou liquido sanguinolento livre na luz traqueal. Histologicamente havia edema e enfisema alveolar e intersticial difuso severo, membranas hialinas espessas aderidas à parede alveolar, espessamento dos septos interlobulares com proliferação de pneumócitos tipo II e infiltrado inflamatório histiocítico, neutrofílico e eosinofílico multifocal moderado a severo. Na traqueia havia hemorragias na submucosa e infiltrado eosinofílico e linfocítico multifocal. Os novilhos com sinais crônicos apresentaram lesões pulmonares semelhantes, entretanto, foram observadas também, fibrose pulmonar multifocal e dilatação cardíaca. O diagnóstico de EEPAB baseou-se na ocorrência da doença após a introdução do rebanho em uma pastagem viçosa em brotação, nas características macroscópicas e histológicas e na ausência de outros agentes tóxicos ou infecciosos que causam lesões semelhantes. Se alerta para os riscos da ocorrência desta enfermidade, quando houver mudanças de pastagens.

TERMOS DE INDEXAÇÃO: Edema pulmonar, enfisema pulmonar, bovinos, Uruguai, L-triptofano, 3-metil-indol, fog fever, pneumonia intersticial atípica, bovino, patologia.

\section{INTRODUCTION}

Acute bovine pulmonary emphysema and edema (ABPE) - also known as atypical interstitial pneumonia, acute pulmonary emphysema, bovine asthma, regrowth fever, or fog fever (Blood 1962, Woolums 2015, Constable et al. 2017) - is a common disease in some regions of the United States and in European countries; however, rare reports are also found in the specific scientific literature of South American countries such as Argentina (Raviolo et al. 2007), Brazil (Wicpolt et al. 2014, Coelho et al. 2017), Chile (Urrutia et al. 1996), and Uruguay (Dutra 2015).

ABPE occurs after ingestion of pastures with high concentrations of the L-tryptophan amino acid. By anaerobic ruminal fermentation is metabolized and converted to indoleacetic acid, subsequently producing the 3-methylindole (3MI) pneumotoxic metabolite (Carlson et al. 1972, Bray \& Emmerson 1994, Skiles \& Yost 1996).

$3 \mathrm{MI}$ reaches the lungs hematogenously, and by action of cytochrome P450 enzymes is converted through dehydrogenation to 3-methylene-indolenine, which is highly electrophilic and the main pneumonotoxic factor of 3MI (Skiles \& Yost 1996, Loneragan et al. 2001a). This substance causes cellular damage on type 1 pneumocytes and on the non-ciliated bronchiolar epithelium (Club cells), resulting in severe pulmonary edema and emphysema, presence of hyaline membranes, and hyperplasia of the alveolar epithelium (Carlson et al. 1972, Bray \& Emmerson 1994, Woolums 2015, Constable et al. 2017). This disease has already been reproduced in cattle experimentally by ingestion of L-tryptophan (Carlson et al. 1972, Wicpolt et al. 2014) and directly by 3MI (Bradley \& Carlson 1980, Logan et al. 1983).

Outbreaks occur more often in adult cattle, with no breed predisposition, in several types of pasture; however, they occur when there is abrupt dietary change, and cattle are moved from drier pastures to green and lush ones (Blood 1962, Urrutia et al. 1996, Raviolo et al. 2007, Woolums 2015, Constable et al. 2017).

Animals present respiratory clinical signs such as orthopneic position, dyspnea, tachypnea, sialorrhea, and expiratory noises. In general, clinical signs manifest as of the third day after feeding, and necropsy findings are basically restricted to the respiratory tract (Blood 1962, Carlson et al. 1972, Loneragan et al. 2001b, Raviolo et al. 2007, Wicpolt et al. 2014, Constable et al. 2017).

To reach a diagnosis, it is necessary to associate the epidemiological aspects, clinical signs, and macroscopic and microscopic changes. There is no specific treatment for ABPE; however, methods of gradual adaptation to new pastures can be employed in cases of sudden dietary change. The use of monensin and lasalocid was also shown to be effective in decreasing the ruminal production of $3 \mathrm{MI}$ (Constable et al. 2017). Association of these two management practices seems to decrease $3 \mathrm{MI}$ production, consequently reducing the incidence of new cases.

The present study aimed to describe an outbreak of pulmonary edema and emphysema in Uruguayan beef cattle, highlighting the occurrence of acute and chronic cases of the disease that determined deaths for a period of approximately 50 days.

\section{MATERIALS AND METHODS}

Epidemiological data were collected, clinical assessment was conducted, and necropsy was performed in six bovines in several visits to the farm. Lung samples were collected from all necropsied animals; they were routinely processed, and $3-5 \mu \mathrm{m}$ histologic sections were obtained for staining with hematoxylin-eosin (HE). Polymerase chain reaction (PCR) was performed in two lung samples for detection of bovine respiratory syncytial virus (BRSV) (Vilcek et al. 1994), parainfluenza virus type 3 (PI3) (Horwood et al. 2008), bovine herpesvirus type 1 (BoHV-1) (Silva et al. 2007), and bovine viral diarrhea virus (BVDV) (Maya et al. 2016).

\section{RESULTS}

\section{Epidemiology}

The outbreak occurred in a herd of Hereford cattle managed under a semi-intensive system in the Department of Colonia, Uruguay. On May 15, 2016 (autumn), 126 Hereford cattle head aged 6-8 months were purchased from the Department of Durazno. Once in the new farm, the steers were placed in a field with native pasture. Coprological examination showed an average of 700 EPG. Sedimentation test was negative for Fasciola hepatica. The bovines were dewormed using a levamisole-based product. After eight days, the steers underwent 
an adaptation phase with supplementation based on hay, broken corn, expeller pressed canola meal and mineral salts that lasted until concentrate intake reached $1 \%$ of live weight.

After the adaptation phase, the animals were allocated to three different Avena sativa paddocks. The pasture had been sown in March 2017 and was fertilized only once with ammonium phosphate. It had previously been grazed by other cattle during the month of June; the assessed animals were introduced in this pasture on June 22 and remained there until July 8 . On July 8 (winter), a group of 40 steers was introduced in a green and lush growing oat pasture that had been sown in May, fertilized twice with ammonium phosphate (100 kg/hectare) and urea (80 kg/hectare), and had never been grazed.

On July 11, the steers that had been moved to the pasture of green and lush Avena sativa presented acute respiratory clinical signs and was moved to a Festuca arundinacea (syn. Lolium arundinaceum) pasture.

\section{Clinical signs}

The outbreak began four days after the pasture change and lasted approximately 50 days, resulting in 20 deaths. Deaths in numbers per week occurred as follows: three in the first week, four in the second, seven in the third, one in the sixth, and five in the seventh week after the change in pasture conditions.

Animals that died in the first three weeks presented the acute form of the disease, with orthopneic position, severe dyspnea, mouth breathing, expiratory noise, dilatation of the nostrils and, in some cases, subcutaneous edema. The animals that died subsequently presented the chronic form of the disease, with dyspnea, permanent respiratory noise, agitation after abrupt changes in environmental temperature, weight loss, marked growth retardation, and intolerance to exercise. Approximately 10 days after the first death, the steers were withdrawn from the pasture; even so, the chronically affected animals continued dying throughout the following 40 days.

\section{Gross and microscopic lesions}

Changes observed at necropsy were similar in most cases. In both acute and chronic cases, the lungs were diffusely distended, dark red with glistening surface, and presented subpleural emphysema with air blebs distributed throughout the pleural surface (Fig.1). At the cut surface, the lungs were firm, rubbery with dark red color showing severe alveolar and interlobular edema and emphysema. The lobules and interlobular spaces were distended by abundant light yellow and gelatinous material and air blebs (Fig.2), The final portion of the trachea, bronchi, and bronchioles had a pink foam material. The first two necropsied animals, up to 72 hours after onset of the clinical signs, presented multifocal hemorrhages and abundant amount of bloody fluid in the tracheal lumen, and severe laryngeal edema (Fig.3 and 4). In the other four animals, necropsied between 10 and 50 days after the first death, the lungs presented a firmer and more fibrous appearance and the heart showed hypertrophy and dilation of the right chambers, especially the right ventricle (cor pulmonale). The right auricle was diffusely dark red in color (Fig.5). Parasitic, filiform, milky-white nematodes, identified as Dictyocaulus viviparus,

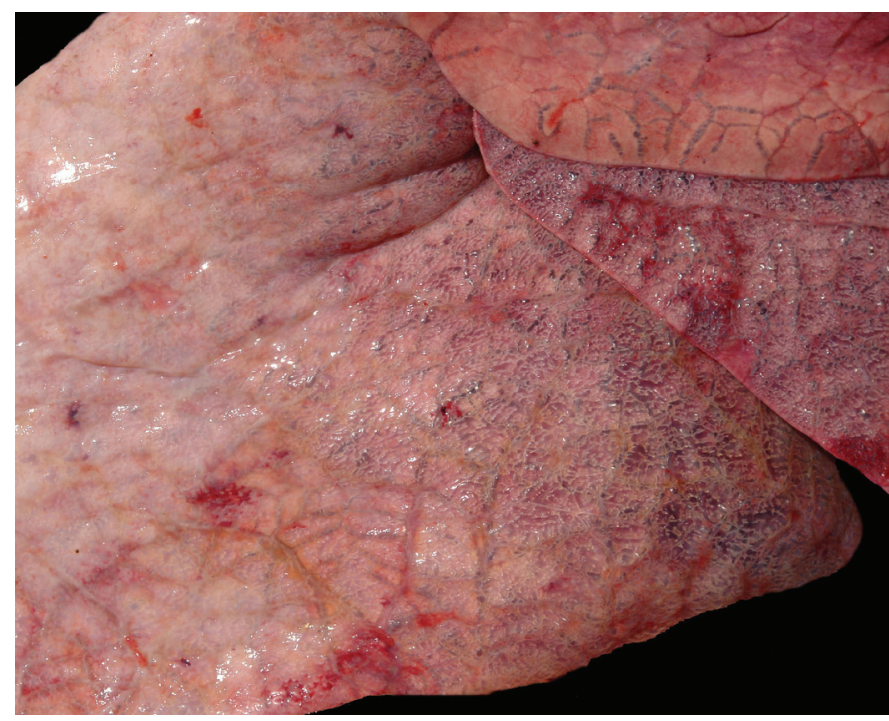

Fig.1. Bovine lung. Diffusely armed, crepitant, edematous and emphysematous bovine lung with abundance of air blebs on the pleural surface.

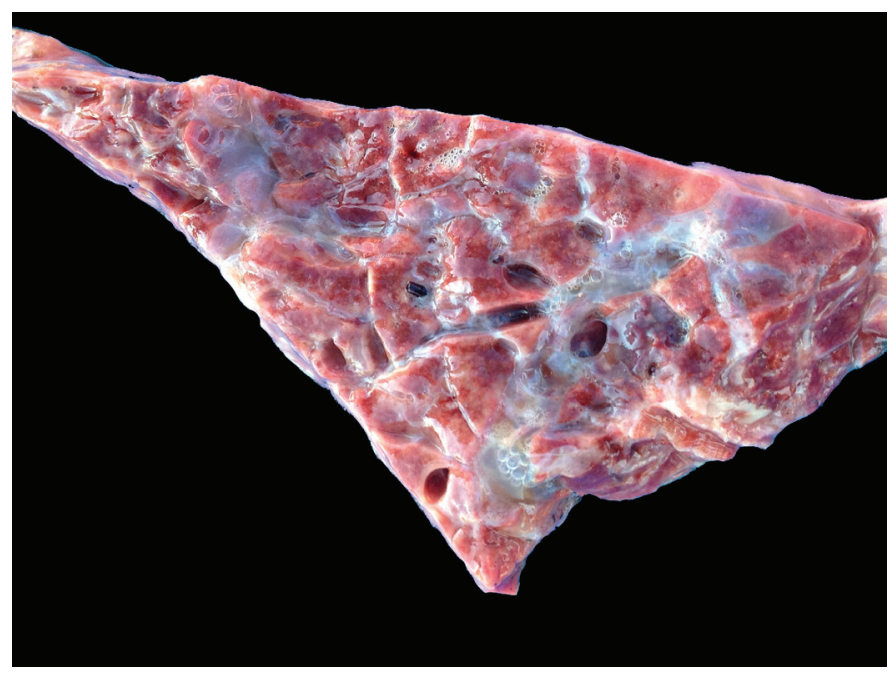

Fig.2. Bovine lung. At the cut surface, the lobules and the interlobular and peribronchial spaces are markedly distended by edema and interlobular emphysema.

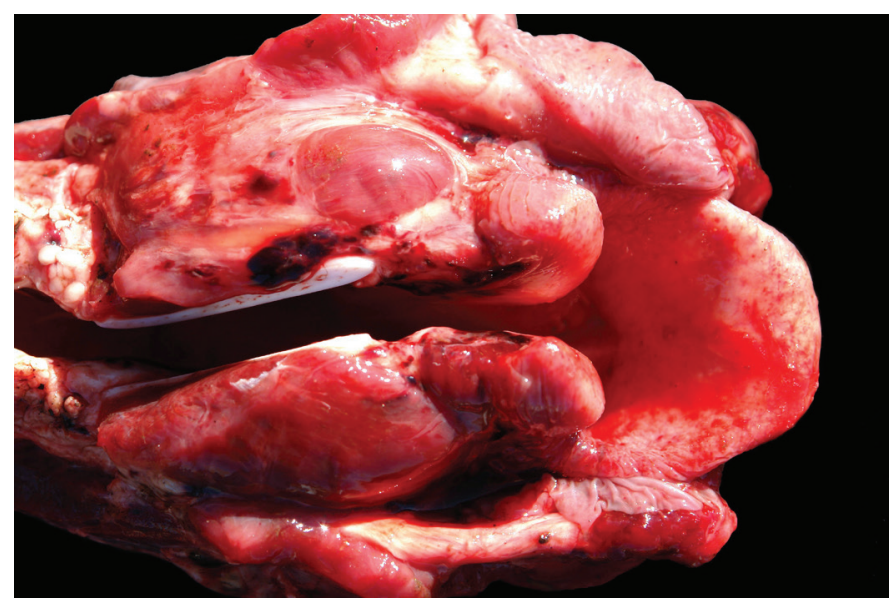

Fig.3. Bovine larynx with severe hyperemia, edema, and increased in volume. 


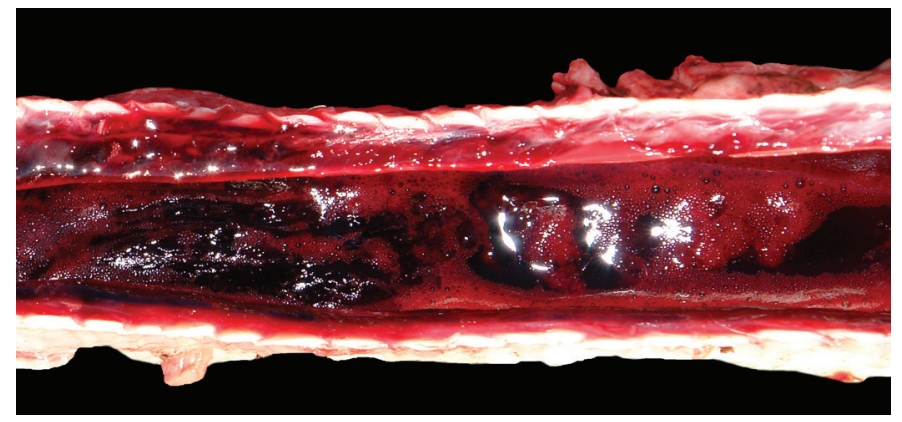

Fig. 4. Bovine trachea with abundance of bloody liquid in the tracheal lumen.

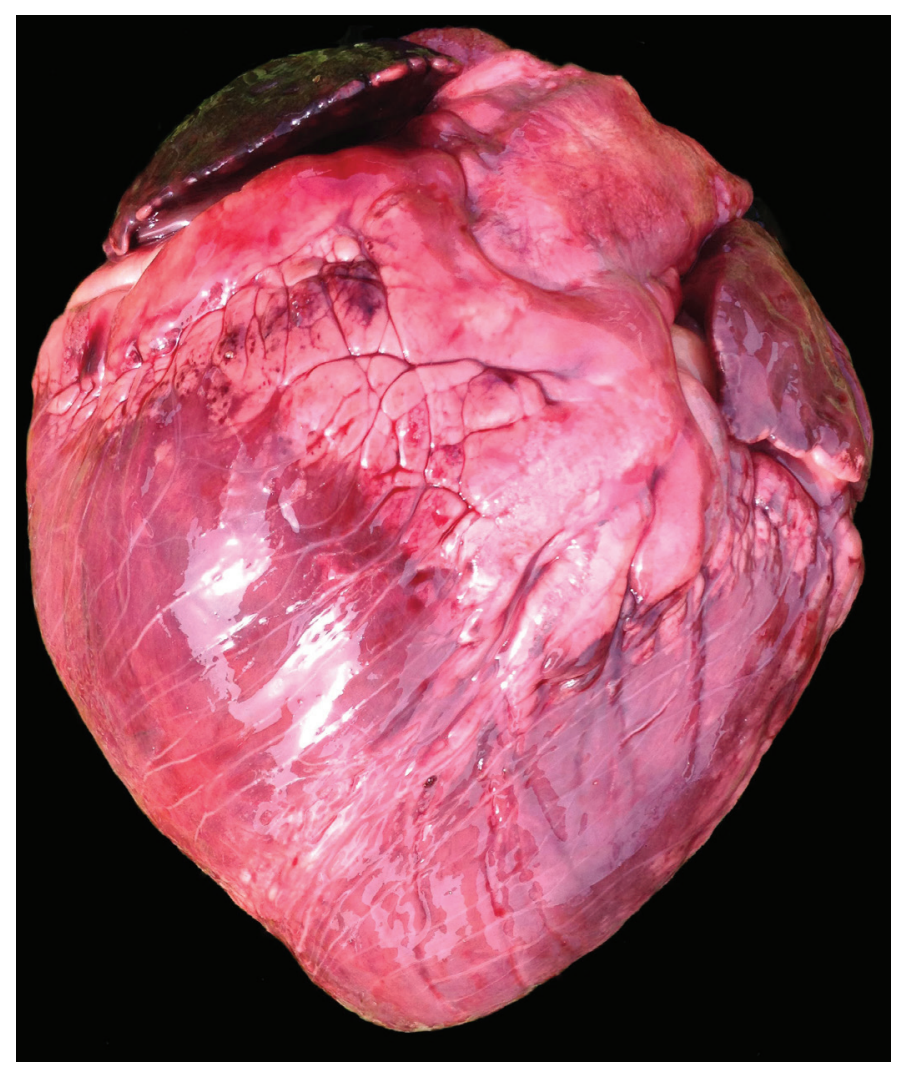

Fig.5. Bovine heart showing hypertrophy and dilation of the right chambers, especially the right ventricle (cor pulmonale).

were observed in three bovines. The last necropsied steer also presented pulmonary abscesses.

Histologic examination showed severe diffuse alveolar and interstitial emphysema, hyaline membranes adhered to the alveolar wall, thickening of the interlobular septae with proliferation of type II pneumocytes, and histiocytic, neutrophilic and eosinophilic infiltrate (Fig.6 and 7). In the trachea of the first two necropsied steers, there were severe multifocal submucosal hemorrhages and moderate eosinophilic and lymphocytic infiltrate. The last necropsied animals also presented proliferation of fibrous connective tissue in the interstitial space. Suppurative, chronically active, multifocal-tocoalescent bronchopneumonia was also observed in the animal with pulmonary abscesses.

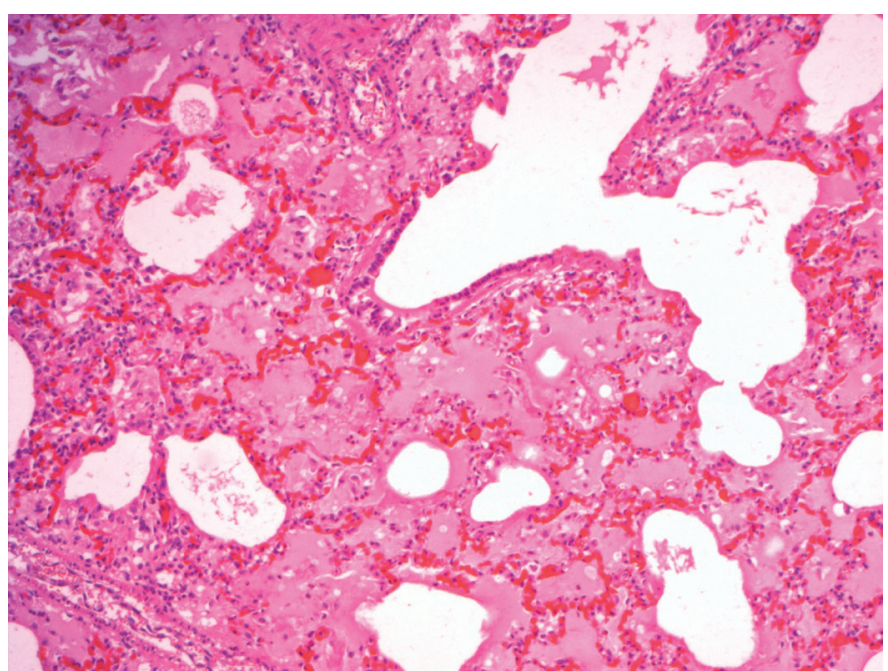

Fig.6. Bovine lung, with acute pulmonary edema and emphysema with proliferation of type II pneumocytes and formation of hyaline membranes strongly adhered to the alveolar wall. HE, obj.10x.

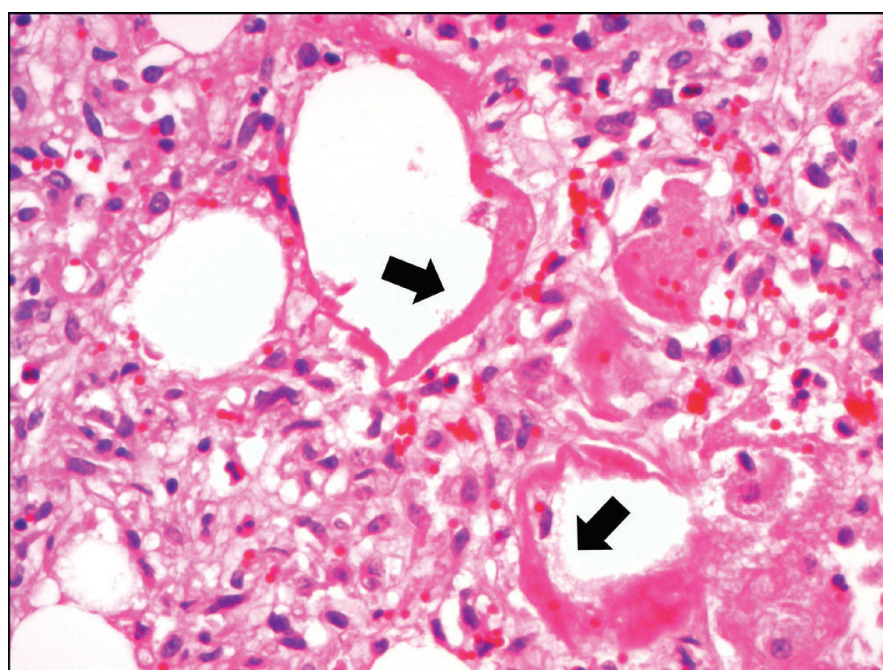

Fig.7. Bovine lung with hyaline membranes strongly adhered to the alveolar epithelium (arrows), proliferation of type II pneumocytes, and discrete histiocytic inflammatory infiltrate. HE, obj.20x.

\section{Microbiology}

No viral genomes of BRSV, BVDV, PI3, and BoHV-1 were detected by the PCR technique in any of the samples.

\section{DISCUSSION}

Diagnosis of acute bovine pulmonary emphysema and edema (ABPE) was established based on epidemiology, acute respiratory clinical signs, and macroscopic and microscopic examinations, which were similar to those reported in other studies (Urrutia et al. 1996, Loneragan et al. 2001b, Raviolo et al. 2007, Doster 2010, Wicpolt et al. 2014, Coelho et al. 2017). The disease usually occurs in autumn (Kerr \& Linnabary 1989), but this outbreak occurred in winter. Outbreaks of ABPE have also been reported at different times of the year in other South 
American countries (Urrutia et al. 1996, Raviolo et al. 2007, Wicpolt et al. 2014).

The respiratory clinical signs of this outbreak, which were like those observed in other countries (Woolums 2015), occurred abruptly approximately four days after pasture change. In Brazil, Wicpolt et al. (2014) described the occurrence of ABPE within 10 days after change in pasture conditions. The disease probably occurs because the rumen microbiota cannot adapt to the metabolism of L-tryptophan when ingested in large amounts (Loneragan et al. 2001a, Wicpolt et al. 2014, Woolums 2015).

In this outbreak, it was possible to observe several phases of the disease. The acute form was evidenced in the first two necropsied animals and presented more severe dyspnea. Other animals developed the chronic form of the disease, which is characterized by cor pulmonale, pulmonary fibrosis, and bronchopneumonia. The latter form has previously been described in some outbreaks of the disease (Woolums 2015, Constable et al. 2017).

Other etiologies that cause acute pulmonary edema and emphysema should be considered for differential diagnosis, including: extrinsic allergic alveolitis; verminotic pneumonias (Kerr \& Linnabary 1989, Doster 2010, Constable et al. 2017); intoxications with mould-damaged sweet potato (Medeiros et al. 2001, Fighera et al. 2003, Doster 2010), Perrilla frutescens (Kerr et al. 1986), Zieria arborenses, Brassica spp., and Acremonium lolli; pneumonia caused by toxic gas inhalation (Woolums 2015); and pneumonia attributed to ingestion of wafer meal (Coelho et al. 2017). All these diseases present similar clinical signs and lesions, and differential diagnosis should be performed mainly based on epidemiology.

Dictyocaulus viviparus infection observed in three of the necropsied steers probably contributed to the severity of the clinical conditions in these animals. Massive reinfection due to the large number of the larval form of this parasite in the pastures can lead to the development of a hypersensitivity reaction that is very similar to ABPE, which occurs two to three weeks after introduction in infected pasture (Constable et al. 2017). However, three important aspects suggest that verminotic pneumonia was not the primary cause: 1) the short time elapsed between the change of pastures and emergence of the clinical signs; 2 ) the small number, or even absence, of D. viviparus in the affected cattle; 3 ) the disease did not occur in other steers of the same herd introduced, at the same time, in different paddocks..

Clinical signs, necropsy and histologic findings of pneumonia by BRSV are difficult to distinguish from those of ABPE (Wicpolt et al. 2014). Experimentally, both respiratory clinical signs and lesions found at necropsy are more severe in animals poisoned by $3 \mathrm{MI}$ and infected with BRSV simultaneously than in those affected by only one of these agents (Bingham et al. 1999).

Laryngeal and tracheal lesions such as edema, petechiae, and ecchymosis may occur in the acute form of ABPE (Woolums 2015, Constable et al. 2017); however, there are no reports of severe hemorrhagic tracheitis as observed in this outbreak. In these cases, it is also necessary to conduct differential diagnosis for infectious bovine rhinotracheitis (IBR) caused by bovine herpesvirus type 1 (BoHV-1) and other viral etiologies of the bovine respiratory complex.
Despite the several reports of ABPE, there are few studies in the literature addressing the chronic phases of spontaneous cases of this disease. Cor pulmonale is an important but poorly described finding resulting from congestive heart failure caused by chronic interstitial pneumonia, which, when associated with pulmonary fibrosis, characterize the chronic form of the disease (Constable et al. 2017). It is difficult to identify the aspects that determined the occurrence of chronic cases of the disease, but climatic factors and the fact that the animals were receiving dietary supplementation with concentrate feeds may have influenced the emergence of its chronic form.

In this outbreak, although the animals were grazing on Aveia sativa pasture, the development phase of the pasture (an old pasture under second grazing and a green, lush, never grazed pasture) was a determining factor for the onset of ABPE, possibly due to the difference in tryptophan concentration between the old and the green lush pastures. Even with the withdrawal of the cattle from the pasture approximately 14 days after introduction, animals that developed the chronic form of the disease eventually died within a period of up to 50 days, confirming that this measure may not be sufficient to interrupt the chronic form of the disease and prevent mortality.

In the past decades, Uruguay has significantly increased its export of grains, thus reducing the amount of land destined to beef cattle raising in the Country (Carriquirry 2015). Due to the loss of pasture area generated by the agricultural sector and the increases in beef prices, there have been changes in the traditional meat production, leading to greater intensification and modernization in land use with increased implantation of cultivated pasture, which is possibly an important epidemiological factor for the incidence of ABPE in the Country.

\section{CONCLUSIONS}

Outbreaks of acute bovine pulmonary emphysema and edema (ABPE) have caused significant economic losses in semi-intensive cattle raising systems in Uruguay.

The diagnosis should be made by associating respiratory clinical signs with presence of ABPE after dietary changes and absence of other toxic or infectious diseases. Once diagnosis is established, animals should be immediately withdrawn from the pasture to minimize losses caused by the disease; however, mortality may continue to occur in chronic cases.

\section{REFERENCES}

Bingham H.R., Morley P.S., Wittum T.E., Bray T.M., West K.H., Slemons R.D., Ellis J.A., Haines D.M., Levy M.A., Sarver C.F., Saville W.J. \& Cortese V.S. 1999. Synergistic effects of concurrent challenge with bovine respiratory syncytial virus and 3-methylindole in calves. Am. J. Vet. Res. 60(5):563570. <PMid:10328425>

Blood D.C. 1962. Atypical interstitial pneumonia of cattle. Can. Vet. J. 3(2):4047. <PMid:17421453>

Bradley B.J. \& Carlson J.R. 1980. Ultrastructural pulmonary changes induced by intravenously administered 3-methylindole in goats. Am. J. Pathol. 99(3):551-560. <PMid:7386595>

Bray T.M. \& Emmerson K.S. 1994. Putative mechanisms of toxicity of 3-methylindole: from free radical to pneumotoxicosis. Annu. Rev. Pharmacol. Toxicol. 34(1):91-115. <http://dx.doi.org/10.1146/annurev. pa.34.040194.000515> <PMid:8042858> 
Carlson J.R., Yokoyama M.T. \& Dickinson E.O. 1972. Induction of pulmonary edema and emphysema in cattle and goats with 3-methylindole. Science 176(4032):298-299. <http://dx.doi.org/10.1126/science.176.4032.298> <PMid:5019784>

Carriquirry F. 2015. El desarrollo agropecuario y agroindustrial de Uruguay. Ministerio de Ganadería, Agricultura y Pesca. Available at <http://www. mgap.gub.uy/sites/default/files/multimedia/el_desarrollo_agropecuario_y_ agroindustrial_de_uruguay._reflexiones_en_el_50_aniversario_de_la_ oficina_de_programacion_y_politica_agropecuaria.pdf> Accessed on February 16, 2018.

Coelho A.C.B., Oliveira P.A., Santos B.L.D., Estima-Silva P., Scheid H.V., Leal S.D.C.B.D., Marcolongo-Pereira C. \& Schild A.L. 2017. Atypical bovine interstitial pneumonia in a semi-intensive beef cattle system. Ciência Rural 47(11):e20170467. <http://dx.doi.org/10.1590/0103-8478cr20170467>

Constable P.D., Hichcliff K.W., Done S.H. \& Grunberg W. 2017. Respiratory system, p.965-969. In: Ibid. (Eds), Veterinary Medicine. 11th ed. W.B. Saunders, Edinburgh.

Doster A.R. 2010. Bovine atypical pneumonia. Vet. Clin. N. Am., Food Anim. Pract. 26(2):395-407. <http://dx.doi.org/10.1016/j.cvfa.2010.03.002> <PMid:20619192>

Dutra F. 2015. Boletín 18: Archivo Veterinario del Este. Available at <https:// www.smvu.com.uy/moduloBiblioteca/13_e751e508/archivosAdjuntos/n-2. pdf $>$ Accessed on Jan. 21, 2018

Fighera R.A., Rozza D.B., Piazer J.V., Copetti M.V., Irigoyen L.F. \& Barros C.S.L. 2003. Pneumonia intersticial em bovinos associada à ingestão de batatadoce (Ipomoea batatas) mofada. Pesq. Vet. Bras. 23(4):161-166. <http:// dx.doi.org/10.1590/S0100-736X2003000400004>

Horwood P.F., Gravel J.L. \& Mahony T.J. 2008. Identification of two distinct bovine parainfluenza virus type 3 genotypes. J. Gen. Virol. 89(Pt 7):16431648. <http://dx.doi.org/10.1099/vir.0.2008/000026-0><PMid:18559934>

Kerr L.A. \& Linnabary R.D. 1989. A review of interstitial pneumonia in cattle. Vet. Hum. Toxicol. 31(3):247-254. <PMid:2662572>

Kerr L.A., Johnson B.J. \& Burrows G.E. 1986. Intoxication of cattle by Perrilla frutescens (purple mint). Vet. Hum. Toxicol. 28(5):412-416.<PMid:3776081>

Logan A., Selman I.E., Wiseman A., Allan E.M. \& Pirie H.M. 1983. Experimental production of diffuse pulmonary fibrosis and alveolitis in cattle: the effects of repeated dosage with 3, methyl indole. Res. Vet. Sci. 34(1):97-108. $<$ PMid:6836186>

Loneragan G.H., Gould A.H., Mason G.L., Garry F.B., Yost G.S., Lanza D.L., Miles D.G., Hoffman B.W. \& Mills L.J. 2001a. Association of 3-methyleneindolenine, a toxic metabolite of 3-methylindole, with acute interstitial pneumonia in feedlot cattle. J. Vet. Res. 62(10):1525-1530.<http://dx.doi.org/10.2460/ ajvr.2001.62.1525><PMid:11592314>

Loneragan G.H., Gould D.H., Mason G.L., Garry F.B., Yost G.S., Miles D.G., Hoffman B.W. \& Mills L.J. 2001b. Involvement of microbial respiratory pathogens in acute interstitial pneumonia in feedlot cattle. Am. J. Vet. Res. 62(10):15191524. <http://dx.doi.org/10.2460/ajvr.2001.62.1519><PMid:11592313>

Maya L., Puentes R., Reolón E., Acuña P., Riet F., Rivero R., Cristina J. \& Colina R. 2016. Molecular diversity of bovine viral diarrea virus in Uruguay. Arch. Virol.161(3):529-535. <http://dx.doi.org/10.1007/s00705-015-2688-4> <PMid:26597189>

Medeiros R.M., Simões S.V., Tabosa I.M., Nóbrega W.D. \& Riet-Correa F. 2001. Bovine atypical interstitial pneumonia associated with the ingestion of damaged sweet potatoes (Ipomoea batatas) in northeastern Brazil. Vet. Hum. Toxicol. 43(4):205-207. <PMid:11474732>

Raviolo J.M., Giraudo J.A., Bagnis G., Lovera H.J., Martínez R., Nora T. \& Zielinski G. 2007. Descripción de um brote de enfisema y edema pulmonar bovino agudo em El Suroeste de Córdoba, Argentina. Téc. Pecu. Méx. 45:111-120.

Silva M.S., Brum M.C.S., Loreto E.L.S., Weiblen R. \& Flores E.F. 2007. Molecular and antigenic characterization of Brazilian bovine herpesvirus type 1 isolates recovered from the brain of cattle with neurological disease. Virus Research 129(2):191-199. <http://dx.doi.org/10.1016/j.virusres.2007.07.014> <PMid:17822796>

Skiles G.L. \& Yost G.S. 1996. Mechanistic studies on the cytochrome P450catalyzed dehydrogenation of 3-methylindole. Chem. Res. Toxicol. 9(1):291297. <http://dx.doi.org/10.1021/tx9501187> <PMid:8924606>

Urrutia H., Brevis C., Quezada M. \& Donoso S. 1996. Descripción de un brote de enfisema y edema pulmonar agudo del bovino (EPAB) em Parral (Chile). Arch. Med. Vet. 29:161-165.

Vilcek S., Elvander M., Ballagi-Pordány A. \& Belák S. 1994. Development of nested PCR assays for detection of bovine respiratory syncytial virus in clinical samples. J. Clin. Microbiol. 32(9):2225-2231. <PMid:7814551>

Wicpolt N.S., Cardoso T.C., Emmerich T., Borelli V., Wisser C.S., Gueller E., Traverso S.D. \& Gava A. 2014. Edema e enfisema pulmonar agudo em bovinos no Sul do Brasil: doença espontânea e reprodução experimental. Pesq. Vet. Bras. 34(12):1167-1172. <http://dx.doi.org/10.1590/S0100736X2014001200004>

Woolums A.R. 2015. Diseases in respiratory system, p.617-628. In: Smith B.P. (Ed.), Large Animal Internal Medicine. 5th ed. Elsevier. 